\title{
DINAMIKA RELASI POLITIK ANTARA OTONOMI GURU DAN DOMINASI KEKUASAAN
}

\author{
${ }^{1)}$ Arif Rohman, ${ }^{2)}$ Noeng Muhadjir, ${ }^{3)}$ Suyata \\ ${ }^{1,2,3)}$ Univeritas Negeri Yogyakarta \\ 1)arv_2013@yahoo.co.id
}

\begin{abstract}
Abstrak
Penelitian ini bertujuan untuk menjelaskan dinamika relasi politik antara otonomi guru dan dominasi kekuasaan. Penelitian dilakukan dengan pendekatan kualitatif fenomenologis. Lokasinya di Kabupaten Bantul. Subjek terdiri dari 37 orang yang dipilih secara purposive. Prosedur penelitian ditempuh dengan lima langkah, dengan metode penggalian data: angket terbuka, wawancara mendalam, dan kajian dokumen. Trianggulasi melalui trianggulasi: metode dan sumber, diskusi ahli, dan penjelasan banding. Analisis data dilakukan secara kualitatif fenomenologis. Temuan penelitian adalah sebagai berikut. Pertama, upaya guru dalam membangun otonominya menuju sosok profesional dipengaruhi oleh dinamika politik. Kedua, terdapat politisasi guru oleh penguasa daerah, yang dilakukan melalui 'praktik terselubung' untuk 'meraih dukungan' dan berujung pada bargaining politik dan sharing kekuasaan. Ketiga, ada dua bentuk politik dominasi penguasa terhadap guru, yaitu melalui 'politik kooptasi' dan melalui 'politik pengambilan hati'. Keempat, politik kooptasi berimplikasi negatif pada melemahnya sikap kritis guru, sedangkan politik pengambilan hati berimplikasi positif pada meningkatnya jumlah guru dalam studi lanjut dan meningkatnya kesejahteraan guru.
\end{abstract}

Kata kunci: relasi politik, otonomi guru, dan dominasi kekuasaan

\section{THE DYNAMICS OF THE POLITICAL RELATION BETWEEN TEACHER AUTONOMY AND POWER DOMINATION}

\author{
${ }^{1)}$ Arif Rohman, ${ }^{2)}$ Noeng Muhadjir, ${ }^{3}$ Suyata \\ ${ }^{1,2,3)}$ Univeritas Negeri Yogyakarta \\ ${ }^{1)}$ arv_2013@yahoo.co.id
}

\begin{abstract}
This study aims to describe the dynamics of political relation between teachers' autonomy and power domination. This study was conducted by means of phenomenological qualitative approach. The setting was Bantul Regency. The subjects consisted of 37 people established through purposive sampling techniques. The research procedure consisted of five steps by means of data collecting methods in the form of an open-ended questionnaire, in-depth interviews, and a document study. The triangulation was conducted through method and source triangulation, expert discussions, and rival explanations. The data were analyzed using the phenomenological qualitative data analysis. The research findings are as follows. First, teachers' attempts to develop their autonomy to be professional figures are influenced by the political dynamics. Second, there is a politicization of teachers by local authorities. This is done through hidden practices to gain supports, and this way results in political bargaining and power sharing. Third, there are two forms of authorities' political domination over teachers: cooptation politics and favor-winning politics. Fourth, cooptation politics has negative implications on the weakening of teachers' critical attitudes, while the favor-winning politics have positive implications on the increasing number of teachers who take further study and on the improvement of teachers' welfare.
\end{abstract}

Keywords: political relation, teacher autonomy, and power domination. 


\section{PENDAHULUAN}

Guru merupakan sosok manusia yang dapat 'digugu' (ditaati) dan 'ditiru' (diikuti). Sosok yang ditaati karena ucapannya memuat nasehat kebenaran (truthfulness) dan kejujuran (fairness) menuju jalan hidup selamat; Sedangkan sosok yang diikuti karena tingkah lakunya mengandung keteladanan akhlak (moral) dan karakter baik (good character). Bukan sebaliknya, sosok guru bukanlah sosok 'wagu' (tak pantas) dan 'saru' (jorok). Citra diri positif yang demikian merupakan label yang telah disematkan masyarakat tradisional kepada guru selama ratusan tahun. Karenanya, guru dianggap mayoritas masyarakat sebagai manusia dengan karakter terpuji yang terpancar dalam bentuk kedalaman ilmu, kebenaran tutur kata, kesantunan perilaku, kesahajaan penampilan, keramahan sapa, kesalehan beribadah, dan ketulusan pengabdiannya. Sosok guru dengan karakter terpuji tersebut pada gilirannya dapat berdampak positif bagi masyarakat sekelilingnya dalam rangka membangun kemajuan peradaban umat manusia.

Sebagai sosok dengan karakter terpuji, peran guru menjadi sangat penting dalam proses transformasi sosial di masyarakat. Hal ini sejalan dengan pendapat Meyer (Hadisusanto, Sidharta, dan Siswoyo, 1995), bahwa guru berperan dalam "a process leading to the enlightenment of mankind". Begitu juga Joni (1991), menyebutkan guru berperan mengembangkan sumberdaya manusia yang dapat menentukan kelestarian dan kejayaan kehidupan bangsa. Oleh karenanya, guru sering bersama masyarakat terlibat dalam penyelesaian persoalan-persoalan kemasyarakatan. Mereka terlibat bersama dalam perjuangan membebaskan masyarakat dari aneka belenggu dan masalah, termasuk di dalamnya terhadap masalah politik. Koesoema (2009) menyebut perjuangan guru bersama masyarakat dalam politik dipahami dalam dua telaah, yaitu: telaah historis-faktual, dan telaah normatifidealis. Telaah historis-faktual merupakan telaah dengan mendasarkan pada data sejarah, sedangkan telaah normatif-idealis merupakan telaah dengan mendasarkan pada konsep, pemahaman, dan nilai yang dipahami guru sebagai pelaku perubahan dalam memandang dunia di mana mereka hidup.

Keterlibatan guru bersama masyarakat dalam mengatasi aneka masalah sosial politik merupakan cerminan relasi antar guru dan masyarakat. Relasi antarkeduanya beserta dinamikanya tersebut terjadi seiring dengan intensitas relasi yang mereka bangun. Melalui keterlibatan guru bersama masyarakat menjadikannya menjadi bagian tak terpisahkan dalam interaksi antar kelompok sosial politik dalam masyarakat.

Spring (1993), berpendapat bahwa dalam proses interaksi antar kelompok masyarakat untuk mewujudkan cita-cita bersama, guru menjadi bagian penting di dalamnya. Guru menjadi bagian tak terpisahkan dalam interaksi bersama dengan aneka kelompok kepentingan dan kelompok politik dalam masyarakat. Kelompok kepentingan merupakan semua organisasi atau kumpulan orang yang berusaha mempengaruhi kebijakan publik yang dirumuskan dan diimplementasikan oleh pemerintah (Almond, 1974). Kelompok kepentingan dibedakan menjadi dua, yaitu kelompok kepentingan politis (political interest groups) dan kelompok kepentingan non-politis (non-political interest groups). Kelompok kepentingan politis menurut Al-mond (1974) memiliki orientasi meraih jabatan politik dalam pemerintahan, sebaliknya kelompok kepentingan non-politis tidak memiliki orentasi meraih jabatan politik dalam pemerintahan.

Secara normatif, guru tidak termasuk pada jenis kelompok pertama tetapi termasuk pada jenis kelompok kedua. Hal ini disebabkan karena guru tidak memiliki motivasi untuk meraih jabatan politik dalam pemerintahan. Guru bertugas mendidik dan mengajar anak-anak di sekolah dengan orientasi mencerdaskan kehidupan bangsa. Namun apakah realitasnya demikian, inilah yang menjadi pertanyaan penting. Beberapa kasus secara tentatif mengindikasikan adanya orientasi guru untuk kepentingan politik. Fenomena demonstrasi guru terhadap kekuasaan politik akhir-akhir ini menunjukkan akan hal itu. Demonstrasi 50 ribu guru 'mengepung' istana Presiden Abdurahman Wahid (Media Indonesia, 19 April 2000). Begitu juga pada era Presiden Susilo Bambang Yudoyono terjadi demonstrasi 28 ribu guru menolak penghapusan Direktorat Jenderal Peningkatan Mutu Pendidikan dan Tenaga Kependidikan (Kompas, 12 Mei 2010). Bahkan tahun 2002, demonstrasi guru di kabupaten Kampar propinsi Riau, berhasil melengserkan Bupati Jefry Noer dari kursi kekuasaannya, atau demonstrasi guru di kabupaten Lombok Timur yang 
berhasil menonaktifkan kekuasaan Bupati Ali Dahlan melalui aklamasi sidang paripurna DPRD setempat (Pantoro, 2010). Pertanyaannya, mengapa demikian? Bagaimana guru relasi guru dengan kekuasaan politik?

Secara teoritik, guru dituntut dapat mengembangkan otonominya menuju profesionalitas dalam mendidik dan mengajar anak. Profesi guru sebagai profesi penting dan strategis yang memiliki tugas memajukan peradaban umat manusia, maka amat memerlukan otonomi yang merujuk pada kedaulatan (sovereignty). Dengan otonomi, profesi guru dapat benar-benar bekerja profesional tanpa dipengaruhi pertimbangan dari luar. Hal ini tercermin pada sumpah guru nomor 8 berbunyi, "Sebagai guru Indonesia saya bersumpah, akan berusaha secara sungguh-sungguh untuk melaksanakan tugas guru tanpa dipengaruhi pertimbangan unsur-unsur di luar kependidikan".

Konsep otonomi di atas amat relevan diterapkan pada diri guru. Profesi guru sebagai profesi penting dan strategis yang memiliki tugas untuk memajukan peradaban umat manusia, maka amat memerlukan kedaulatan (soverignty) yang didukung dengan analisis dan pertimbangan matang. Dengan otonomi, profesi guru diharapkan benar-benar dapat lebih berdaulat dalam melaksanakan tugas-tugas profesi yang profesional tanpa dipengaruhi pertimbangan dari luar. Berdasarkan argumen tersebut, maka otonomi guru dimaknai sebagai kemandirian guru dalam melakukan banyak hal yang terkait dengan profesi guru. Dengan demikian otonomi guru merupakan otonomi profesi sebagai seorang guru yang profesional. Sebagai seorang guru profesional, ia dituntut untuk sungguh-sungguh meningkatkan keharusan profesional.

Otonomi guru ditunjukkan oleh kemampuannya untuk menentukan sikap dan perilakunya sendiri tanpa harus ada campur tangan orang lain, tetapi juga harus berani mempertanggungjawabkan perilaku pilihannya. Sepanjang menyangkut profesi guru, perilaku pilihannya harus dapat dipertanggungjawabkan secara filosofis, teoretis-edukatif, dan sosiokultural kepada anak didik, orang tua, sekolah, pemerintah, dan masyarakat luas.

Otonomi guru merupakan otonomi profesi yang dimiliki guru dalam menjalankan tugas-tugas profesi yang profesional, meliputi tugas mendidik, mengajar, membimbing, me- latih, menilai dan mengevaluasi peserta didik di sekolah. Otonomi profesi guru berdasarkan landasan hukum dengan prinsip-prinsip profesionalitas sebagaimana tertuang di dalam Undang-Undang RI Nomor 14 tahun 2005 tentang Guru dan Dosen pada pasal 7 ayat (1) yaitu memiliki tanggungjawab atas pelaksanaan tugas keprofesionalan, antara lain: (a) Merencanakan, melaksanakan, menilai, dan mengevaluasi proses pembelajaran yang bermutu; (b) Meningkatkan dan mengembangkan kualifikasi akademik dan kompetensi secara berkelanjutan sejalan dengan perkembangan ilmu pengetahuan, teknologi, dan seni.

Pada bagian lain, guru dengan peran dan tanggungjawabnya terhadap aneka problem masyarakat menuju kemajuannya, menjadikan mereka tidak dapat menghindar dari relasi dan interaksi dengan aneka kelompok kepentingan (interest group) masyarakat. Bahkan menurut Apple (Tilaar, 2003), guru dan pendidikan memiliki relasi esensial dengan kekuasaan. Kekuasaan negara mencakup segenap pengaturan kehidupan masyarakat, termasuk kehidupan pendidikan dan guru. Penguasa memiliki kepentingan terhadap guru, sebaliknya guru juga menaruh harapan besar atas perhatian penguasa.

Relasi antara guru dan penguasa secara normal dapat berlangsung secara fungsionalsimbiotik. Artinya keduanya memiliki relasi saling menguntungkan. Namun pada banyak kasus tidak selamanya bisa berlangsung positif, akan tetapi negatif berupa pola relasi eksploitatif dan dominatif. Pola relasi negatif tersebut hanya menguntungkan satu pihak yaitu penguasa, sedangkan guru kurang diuntungkan bahkan ditindas hanya untuk melayani kepentingan kekuasaan.

Perspektif teori konflik, menjelaskan di dalam sistem sosial tidak selamanya terdapat keteraturan akan tetapi justru ketegangan dan pertentangan. Dalam kasus di atas, ketegangan dan pertentangan terjadi antara guru dengan penguasa. Proses ketegangan dan pertentangan melahirkan dominasi (domination), koersi (coercion), dan opresi (oppression). Baik guru dan penguasa memiliki otoritas berbeda, yang pada akhirnya menghasilkan pemisahan kutub kekuatan sosial yaitu subordinasi dan superordinasi (Ritzer, 1996).

Pola relasi pertentangan yang kurang seimbang tersebut, guru sering hanya dijadikan sebagai alat kepentingan kekuasaan. 
Banyak kasus di daerah berupa aneka praktek ketidakadilan penguasa daerah terhadap guru. Laporan Republika menyebutkan, "Saat pelaksanaan pilkada, banyak kepala daerah main ancam guru akan dimutasi ke daerah terpencil atau diturunkan statusnya dari kepala sekolah menjadi guru bantu, seperti yang terjadi pada beberapa kabupaten dan kota" (Republika, 22 Nopember 2011). Menurut Laksana (2011), praktek kekuasaan despotik yang diperagakan penguasa daerah terhadap guru melalui bentuk-bentuk mutation (pergeseran) dan demotion (penurunan) atas tugas-tugas kedinasan guru sudah sering terjadi.

Ahli lain Giroux dan Mc Laren (1989) menguatkan bahwa guru bersama warga sekolah dimanfaatkan oleh penguasa dominan dijadikan sebagai instrumen untuk mendukung the logic of domination and oppression. Lebih jauh guru dieksploitir sedemikian rupa untuk menanamkan watak kepatuhan warga terhadap kekuasaan. Inilah yang oleh Gramsci (Sugiono, 1999) guru dimanfaatkan oleh penguasa menjadi alat hegemoni. Dengan strategi ini, dua keuntungan dapat dipetik penguasa: (1) Terwujudnya mentalitas kepatuhan warga atas dominasi penguasa. (2) Tercapainya resiko minimal bila penguasa memakai alat birokrasi atau polisi untuk menguasai warga. Oleh karenanya, dengan dalih demi pembaharuan pendidikan, menurut Collins (1979) guru telah diarahkan dan dibentuk sedemikian rupa untuk menjadi alat efektif dalam melanggengkan kekuasaan dominan (rezim).

\section{METODE PENELITIAN}

Pendekatan yang dipilih dalam penelitian ini adalah kualitatif fenomenologis, karena karena memungkinkan peneliti membekali diri dengan teori dan hipotesis secara tentatif untuk dikembangkan di lapangan secara berkelanjutan berdasarkan temuan empirik. Pendekatan ini membolehkan peneliti dengan frames and system of interpretation memberikan makna lebih jauh dari empiri, juga memungkinkan peneliti bergerak dari sebagai alat untuk mengungkap intensionalitas subjek yang diteliti yaitu guru dan penguasa daerah. Pendekatan kualitatif fenomenologis yang dipilih lebih berakar pada teori interpretif Michel Foucault dan Jürgen Habermas.
Penelitian dilakukan di kabupaten Bantul, propinsi Daerah Istimewa Yogyakarta, dengan subjek dipilih secara purposive yang berasal dari unsur kepala sekolah, guru, pengawas, ketua Kelompok Kerja Guru (KKG), kepala UPT Pengelola Pendidikan Dasar (PPD), pengurus organisasi serikat guru (PGRI dan PGSI), pejabat pemerintah kabupaten Bantul, Pejabat Dinas Pendidikan Dasar, dan pimpinan Dewan Perwakilan Rakyat Daerah (DPRD) Bantul. Subjek yang berasal dari unsur kepala sekolah dan guru dibedakan dahulu secara cluster (negeri dan swasta) baru kemudian masing-masing dipilih secara purposive. Secara keseluruhan, subjek yang terpilih berjumlah 37 orang subjek.

Penelitian dilakukan dengan lima langkah prosedural meliputi: tahap awal, tahap pengembangan rancangan, tahap pendalaman, tahap penyusunan, dan tahap akhir atau penyajian hasil. Pencarian data dilakukan melalui tiga cara: angket terbuka, wawancara mendalam, dan kajian dokumen. Angket terbuka berisi pertanyaan-pertanyaan tentang pendapat, persepsi, dan kesaksian subjek terpilih tentang otonomi guru dan dominasi kekuasaan, diberikan kepada subjek guru. Wawancara mendalam berisi pertanyaanpertanyaan dialogis yang ditujukan kepada semua kelompok subjek, khusus guru hanya dipilih 10 orang yang diwawancarai dari 60 orang guru yang diberi angket. Wawancara dilakukan untuk menggali jenis data verbal tentang ide, pendapat, persepsi, dan kesaksian para subjek tentang otonomi guru dan dominasi kekuasaan. Wawancara juga dipakai sebagai pendalaman lebih jauh atas temuan dari data angket dan hasil kajian dokumen. Adapun kajian dokumen dilakukan peneliti dengan cara pengumpulan dan pengkajian data politik dan data kepegawaian yang dimiliki oleh dinas pendidikan dasar dan kantor Sekretariat Daerah Pemerintah Kabupaten Bantul. Dengan demikian ketiga-tiganya, baik angket, wawancara, dan kajian dokumen, dipakai oleh peneliti secara komplementer atau saling melengkapi satu dengan yang lain. Peneliti meyakini bahwa tidak ada satu metode yang efektif dipakai untuk menggali semua jenis data yang berasal dari semu sumber data. Trianggulasi dipakai tiga jenis trianggulasi, yaitu metode dan sumber, trianggulasi diskusi ahli, dan trianggulasi rival explanations. 
Adapun analisis datanya adalah kualitatif fenomenologis sebagaimana yang diusulkan oleh Creswell (2007), yaitu melalui langkah-langkah analisis: (1) data managing, (2) reading and memoing, (3) describing, (4) classifying, (5) interpreting, dan (6) visualizing.

\section{HASIL DAN PEMBAHASAN}

Bahwa peningkatan otonomi guru menuju sosok profesional adalah upaya yang banyak dipengaruhi oleh dinamika politik. Pengaruh tersebut antara lain datang dari pejabat pemerintah daerah, pimpinan DPRD, dan pengurus PGRI. Umumnya mereka menginginkan peningkatan otonomi guru agar diarahkan untuk peningkatan kemampuan profesional yang dapat mendukung pencapaian kemajuan masyarakat. Sedangkan pihak guru menginginkan peningkatan otonominya merupakan wujud dari upaya guru dalam memenuhi kewajiban dari tuntutan undangundang, berupa peningkatan kualifikasi dan kompetensi guru demi kemajuan pendidikan.

Peningkatan otonomi guru merupakan tuntutan zaman seiring dengan peningkatan perubahan kehidupan masyarakat yang pada gilirannya berpengaruh pada perubahan sekolah dan pendidikan. Untuk itu, peningkatan otonomi guru adalah keharusan sejarah. Hal tersebut sesuai dengan pendapat Raka Joni (Semiawan dan Soedijarto, 1991) yang menyebutkan pentingnya peningkatan kualitas guru karena hakikat tugas guru berhubungan dengan pengembangan sumberdaya manusia. Keberhasilan tugas guru sangat menentukan kelestarian dan kejayaan kehidupan bangsa, karena tugas guru adalah membangun dasardasar dan corak kehidupan umat manusia di masa mendatang. Begitu juga oleh Frederick Meyer (Hadisusanto, Sidharta, dan Siswoyo, 1995), peningkatan otonomi guru amat penting, karena guru memiliki peran amat menentukan dalam proses pencapaian "the enlightenment of mankind".

Dalam pandangan guru, upaya meningkatkan otonominya adalah sebuah kewajiban yang harus dijalankan sebagaimana telah diatur dalam undang-undang. Hal ini merupakan bentuk kesadaran deontologis yang dimiliki guru sebagai bentuk tanggung-jawabnya atas status yang disandangnya. Kesadaran deontologis sebagai seorang guru tersebut diarahkan untuk menjalankan amanat Undang-Undang RI Nomor 14 tahun 2005 tentang Guru dan Dosen. Sesuai dengan isi undang-undang tersebut, ada dua kewajiban yang harus dijalankan guru yaitu peningkatan kualifikasi akademik dan kompetensi keguruan. Kewajiban meningkatkan kualifikasi akademik yaitu kewajiban guru untuk menempuh studi lanjut sampai ke taraf diploma IV atau sarjana strata-1 (S-1). Sedangkan kewajiban meningkatkan kompetensi keguruan berupa keharusan guru menguasai empat kompetensi yaitu: pedagogik, kepribadian, profesional, dan sosial. Dengan demikian sesuai dengan kesadaran deontologis guru di atas, maka peningkatan kualifikasi akademik dan kompetensi keguruan adalah bentuk realisasi dari otonomi guru.

Mayoritas guru memahami bahwa peningkatan otonomi merupakan upaya meningkatkan kualifikasi akademik dan kompetensi. Guru yang otonom adalah guru yang independen dan tidak terombang-ambing oleh kepentingan politik. Puncak pengembangan otonomi guru adalah diperolehnya jati diri yaitu karakter dan kedaulatan diri.

Guru yang berstatus negeri cenderung loyal pada aturan dan atasan, namun netral dari politik. Sementara guru yang berstatus swasta cenderung loyal pada diri sendiri yang ingin mengabdi untuk kemajuan pendidikan, namun tidak netral dari politik. Para guru mengakui bahwa keterlibatan mereka dalam politik lebih bersifat pribadi sebagai warga negara, terlepas dari statusnya sebagai guru. Praktek politik praktis dilakukan guru secara sembunyi-sembunyi yang mereka sebut 'main lewat belakang'. Guru swasta cenderung terlibat politik praktis secara terang-terangan melalui kontrak politik, demonstrasi, dan audiensi. Hal ini merupakan bagian dari strategi untuk memperjuangkan nasib.

Usaha guru dalam meningkatkan kualifikasi akademik ditempuh melalui studi lanjut ke jenjang pendidikan diploma IV atau strata-1 dan strata-2, sedangkan kewajiban meningkatkan kompetensi ditempuh melalui berbagai cara. Kompetensi pedagogik ditempuh melalui perbaikan perancangan pembelajaran, pemilihan bahan ajar, pemahaman teori dan praktek pembelajaran, perbaikan metode dan media pembelajaran, perbaikan lingkungan belajar secara periodik, pembelajaran remidial yang dilakukan dalam KKG, loka- 
karya sekolah, dan diklat. Kompetensi kepribadian ditempuh melalui pemahaman dan pengamalan agama, meningkatkan sikap bijaksana dan wibawa, perilaku disiplin, dan keteladanan diri bagi siswa dalam penampilan, perkataan, dan perbuatan yang dilakukan dalam usaha praktek nyata, KKG, dan bimbingan kepala sekolah. Kompetensi sosial ditempuh melalui kerjasama harmonis dengan semua warga sekolah, komunikasi akrab antar sesama guru, kepala sekolah, dan orang tua/ wali, diskusi dengan orang tua tentang perkembangan siswa, dan menyelesaikan aneka masalah kehidupan bersama di sekolah yang dilakukan secara kolektif dan bimbingan kepala sekolah. Adapun kompetensi profesional ditempuh melalui pemahaman materi pendidikan terus menerus, studi lanjut, pemanfaatan TIK untuk peningkatan penguasaan materi yang dilakukan secara mandiri, berdiskusi di dalam KKG, lokakarya sekolah, mengikuti diklat dan seminar. Kepekaan, kepedulian, saran, briefing, penugasan, dan bantuan dana dari kepala sekolah diperlukan dalam membantu pengembangan kompetensi guru.

Terdapat politik dominasi oleh penguasa daerah terhadap otonomi guru yang lebih dikenal dengan 'politisasi guru' baik secara tersurat maupun tersirat untuk meraih 'kepentingan politik'. Praktek tersebut merupakan wujud dari political relation yang menjelma menjadi transaksi politik atau political bargaining yang berujung pada power sharing atau pembagian 'kue kekuasaan'.
'Politisasi guru' sudah dirancang sedemikian rupa oleh penguasa daerah dalam bentuk 'praktek terselubung' secara sembunyi-sembunyi agar tidak diketahui oleh pihak lain. Praktek tersebut mereka namakan praktek 'di belakang layar' atau 'main belakang'. Dari luar seolah tidak terjadi apa pun, pihak yang akan mempermasalahkannya sulit menemukan buktinya, akan tetapi secara terselubung terjadi political bargaining. Tujuan 'politisasi guru' oleh penguasa daerah adalah untuk 'meraih dukungan' dari masyarakat luas melalui guru sebagai bentuk legitimasi, karena guru merupakan massa terdidik yang diyakini memiliki 'posisi strategis'. Politisasi guru merupakan bentuk usaha penguasa daerah dalam mencari jenis legitimasi instrumental, karena penguasa akan dan telah memberikan kesejahteraan material dan jabatan bagi guru-guru di Bantul.

Tugas guru melaksanakan 'pekerjaan politik' bukan tanpa imbalan, karena terbukti hasilnya memuaskan sang penguasa. Hasil Pemilukada 2010 calon dari penguasa menang telak (68\%). Sampai awal tahun 2013, hampir tidak ada gejolak politik. Atas jerih payah mereka, penguasa daerah memberikan 'imbalan jasa politik' dalam bentuk 'jabatan politik'.

Untuk itu, imbalan yang diterima guru adalah diterimanya banyak jabatan politik dalam birokrasi pendidikan dari penguasa daerah. Paling tidak ada 10 (sepuluh) jabatan yang pejabatnya diangkat dari latar belakang sebagai guru. Berikut ini daftar jabatan yang pejabatnya diangkat dari guru yang dirangkum dalam Tabel 1.

Tabel 1. Jabatan yang Pejabatnya Berasal dari Guru

\begin{tabular}{ll}
\hline No & Jabatan dengan Pejabatnya Berasal dari Guru \\
\hline 1. & Kepala Dinas Pendidikan Dasar \\
2. & Kepala Dinas Pendidikan Menengah dan Nonformal \\
3. & Kepala Kantor Inspekorat Daerah \\
4. & Kepala Kantor Pemuda dan Olahraga \\
5. & Kepala Bidang Menengah Umum Dinas Pendidikan Menengah dan Nonformal \\
6. & Kepala Bidang Menengah Kejuruan Dinas Pendidikan Menengah dan Nonformal \\
7. & Kepala Bina Program Dinas Pendidikan Dasar \\
8. & Sekteratis Dinas Pendidikan dasar \\
9. & Kepala Bidang Sekolah Dasar Dinas Pendidikan Dasar \\
10. & Kasi Kurikulum Sekolah Dasar Dinas Pendidikan Dasar \\
11 & Kasi Kurikulum SMA Dinas Pendidikan Menengah dan Nonformal \\
\hline
\end{tabular}

(Sumber:BKD Bantul, 2012) 
Secara teoritik, praktek politisasi guru oleh penguasa menurut Wong (2006), Wagman (2003), dan Rubin \& Fausset (2005) disebut sebagai political relation yang berimplikasi pada political interest. Proses relasi politik untuk meraih kepentingan politik secara negatif dapat berujung pada political conflict, namun bila berlangsung secara positif akan berujung pada tawar menawar politik atau political bargaining (Sack (2002), yang oleh Davies (1997) disebut power sharing.

Tujuan dari semua praktek 'politisasi guru' oleh penguasa daerah tersebut adalah dalam rangka 'meraih dukungan' dari masyarakat luas melalui guru, mengingat guru merupakan massa terdidik yang memiliki peran penting di dalam masyarakat, dalam bahasa mereka guru memiliki 'posisi strategis'. Dalam perspektif politik, upaya penguasa untuk mencari dukungan dari massa pendukung disebut upaya mencari legitimasi. Dalam hal ini, upaya dari pihak penguasa daerah mencari penerimaan dan pengakuan guru atas hak moral pemimpin untuk memerintah, membuat, dan melaksanakan keputusan politik (Surbakti, 1992).

Secara teoritik, ada lima jenis legitimasi, yaitu: tradisional, kualitas pribadi, formal-prosedural, instrumental, dan ideologi (Surbakti, 1992). Dalam hal kasus yang sedang diteliti ini, maka upaya penguasa daerah Bantul yang melakukan politisasi terhadap guru termasuk jenis legitimasi instrumental, karena penguasa menjanjikan jaminan atau telah melaksanakan kesejahteraan material dan jabatan bagi guruguru yang ada di wilayah Bantul.

Pengakuan paling nyata atas adanya politisasi guru adalah datang dari mantan ketua PGSI (Persatuan Guru Swasta Indonesia) kabupaten Bantul. Dari pengakuannya diketahui bahwa 'politisasi guru' memang ada meskipun tidak diakui oleh Sekda dan mantan Bupati. Praktek politik yang menggiring guru ke arah politik tertentu tersebut diistilahkan dengan 'menarik guru ke arah politik praktis'. Usaha menarik guru ke arah politik praktis ini secara terbuka diakui terjadi pada guru-guru swasta yang menurutnya relatif mudah dilakukan. Usaha untuk menarik guru swasta dilakukan dengan diberi iming-iming, sehingga mereka amat rentan menjadi asset politik.

Guru-guru negeri yang berstatus PNS pun dapat ditarik ke politik, padahal sesuai aturan PNS harus netral dan tidak boleh berpolitik praktis. Akan tetapi berdasarkan pengakuan dari mantan ketua PGSI Bantul disebutkan bahwa banyak guru-guru PNS yang berkampanye untuk mendukung caloncalon tertentu. Dalam pentas ruang publik, mereka 'berjalan lurus-lurus saja' alias netral tidak terlibat dalam politik praktis, akan tetapi dibalik itu semua mereka 'main di belakang' alias berkampanye untuk kepentingan politik penguasa. Bahkan dalam melakukan kampanye politik, para guru PNS berperan 'sebagai otaknya' yang bekerja 'di belakang layar'.

Tugas untuk mengerjakan 'tugas politik' yang dilakukan oleh PNS tersebut dilakukannya bukan tanpa imbalan. Meskipun tugas tersebut menyimpang dari paraturan pegawai negeri, akan tetapi mereka tetap bertugas dengan baik, terbukti hasilnya memuaskan sang penguasa. Hasil Pemilukada menang telak yaitu mencapai $68 \%$ untuk kandidat yang diusung oleh penguasa. Bahkan sampai akhir tahun 2012, gejolak politik yang dilakukan oleh guru sebagaimana terjadi di daerah lain hampir tidak ada. Atas jerih payah mereka yang diberi 'tugas politik' itulah, akhirnya mereka mendapatkan 'imbalan jasa politik' dalam bentuk 'jabatan politik'.

Praktek pembagian 'kue kekuasaan' politik tersebut secara teoritik, berlaku sebuah adagium yang berbunyi "tidak ada makan siang yang gratis". Hal ini berarti bahwa pemenang haruslah memberikan imbalan pantas kepada para pendukungnya. Dengan demikian menyebabkan berlakunya adagium yang kedua yaitu "siapa mendapat apa", yang berarti bahwa kepantasan imbalan dari pemenang sepadan dengan kuat lemahnya dukungan yang diberikan kepadanya.

Menurut Wong (2006), political relation sebagaimana ditampakkan oleh penguasa daerah dan elit-elit guru di atas dapat berujung pada political sharing atau political concession. Hal ini sebagaimana terjadi di Amerika Serikat. Wong (2006) menyebutkan dalam kasus di Amerika Serikat bentuk imbal jasa penguasa kepada guru berupa perbaikan sistem akreditasi sekolah, penguatan peran kepemimpinan sekolah, reformasi sekolah, serta peningkatan secara drastis mutu sekolah. Dalam penelitian ini, bentuk imbal jasa penguasa kepada guru yang telah membantu dalam proses politik di atas antara lain berupa 
pemberian jabatan penting dalam birokrasi pemerintahan pemkab Bantul.

Ada dua bentuk politisasi guru oleh penguasa daerah dalam menguasai guru, yaitu melalui politik kooptasi atas organisasi federasi guru, dan melalui politik pengambilan hati guru. Politik kooptasi dilakukan oleh penguasa daerah dengan cara menguasai PGRI sebagai organisasi guru terbesar di kabupaten Bantul. Hal ini dapat dicermati pada perangkapan jabatan kepala Dinas Pendidikan Dasar Pemerintah kabupaten Bantul sekaligus juga sebagai ketua PGRI Bantul. Perangkapan jabatan ini diakui sendiri oleh yang bersangkutan, bahwa dia tengah menjalankan tugas ganda karena telah ditunjuk oleh Bupati untuk menjadi kepala Dinas Pendidikan Dasar Pemkab Bantul serta pada saat yang sama juga dipercaya oleh para anggota untuk menjadi ketua PGRI kabupaten Bantul.

Rangkap jabatan di atas menurut pemahaman yang bersangkutan merupakan amanah dan kepercayaan yang harus dijalankan sebagai tugas berat. Diakuinya bahwa, "tugas berat dalam mengemban amanat harus saya laksanakan selain menjadi kepala Dinas Pendidikan Dasar, saya juga sebagai ketua PGRI Kabupaten Bantul. Pengalaman menjadi pengurus di PGRI sudah saya jalani relatif lama mulai menjadi seksi organisasi, kemudian sekretaris bidang lalu wakil ketua, dan sekarang sebagai ketua PGRI Bantul hingga dua periode sampai dengan tahun 2014".

Politik pengambilan hati dilakukan dengan dua jurus, yaitu jurus pemberian dana bantuan studi lanjut dan jurus pemberian insentif peningkatan kesejahteraan. Banyak pihak mencurigai adanya motif terselubung di balik pemberian dana-dana tersebut. Mereka memahami hal tersebut sebagai 'jurus mengambil hati' dari rezim penguasa daerah terhadap guru. Kedua program tersebut diistilahkan sebagai program untuk 'menarik simpati' atau 'memanjakan' dan 'menyenangkan' guru. Disebabkan guru merupakan profesi dengan jumlah personil paling banyak secara kuantitatif. 'Pengambilan hati' sebagai kepentingan politik rezim berkuasa agar tetap mendapat dukungan dari guru untuk tetap berkuasa selama mungkin, minimal sampai periode kedua kekuasaannya dan periode istrinya.
Akibat dari politisasi guru oleh penguasa daerah melalui dua cara yaitu melalui politik kooptasi organisasi federasi guru dan politik pengambilan hati guru yang tertuang di dalam program bantuan studi lanjut dan program pemberian insentif peningkatan kesejahteraan guru, maka pada gilirannya memiliki implikasi terhadap pengembangan profesionalisme guru, baik yang negatif maupun positif.

Politisasi guru oleh penguasa daerah berupa politik kooptasi sekaligus politik akomodasi terhadap organisasi federasi guru berimplikasi negatif, yaitu implikasi yang berupa melemahnya sikap kritis mayoritas guru terhadap aneka kebijakan pendidikan yang dilakukan oleh penguasa daerah. Melemahnya sikap kritis mayoritas guru tersebut antara lain diindikasikan sebagai akibat dari pola relasi dan interaksi aktoraktor penentu kekuasaan di Bantul yang bersifat dominatif. Ada dua aktor penentu dalam formulasi dan implementasi kebijakan pendidikan khususnya menyangkut guru SD, yaitu: Bupati sebagai kepala pemerintahan daerah dan kepala dinas pendidikan dasar beserta aparaturnya. Kedudukan DPRD sebagai institusi pengawas pembangunan pendidikan kurang optimal dalam menjalankan tugas kepengawasan tersebut.

Pola relasi antar aktor penentu kebijakan pendidikan tersebut menunjukkan ketimpangan interaksi yang menjurus pada adanya pola relasi dominan dan sub-dominan satu dengan yang lain dalam mengatur urusan publik di bidang pendidikan. Bupati sebagai pusat kekuasaan mendominasi aparatur di bawahnya khususnya dinas pendidikan. Pola relasi dominasi tersebut, apabila ditarik garis proyeksi akan berlanjut dominasi aparatur dinas pendidikan terhadap kepala sekolah. Berikutnya terjadi dominasi kepala sekolah atas guru. Pola relasi dominatif kekuasaan atas guru tersebut secara psikologi sosial dapat berdampak pada melemahnya sikap dan kinerja guru dalam menjalankan tugas-tugas belajar mengajar khususnya dan melemahnya otonomi guru dalam mewujudkan profesionalisme pada umumnya.

Pada penelitian ini, melalui kooptasi terhadap PGRI menjadikan pola relasi kekuasaan dominatif yang dilakukan Bupati semakin memiliki pengaruh kuat dalam 'mencengkeram' guru. Kooptasi kekuasaan 
Bupati melalui PGRI dapat melemahkan daya kritis guru. Kooptasi terhadap PGRI oleh penguasa daerah di Bantul dilakukan melalui penguasaan para elitnya. PGRI Kabupaten Bantul dipimpin oleh seorang ketua yang sekaligus merangkap sebagai kepala Dinas Pendidikan Dasar (Dikdas), beberapa pengurus harian PGRI juga sebagai pejabat penting di lingkungan Dinas Dikdas dan Dikmenof. Bahkan ada enam pengurus harian PGRI yang sekaligus juga sebagai pejabat di lingkungan Dinas Dikdas dan Dinas Dikmenof. Hal inilah yang antara lain menjadikan PGRI tidak punya taring di hadapan penguasa daerah.

Lemahnya sikap kritis mayoritas guru tersebut diwakili oleh lemahnya keberanian organisasi federasi guru kepada pemerintah daerah. Kritik terbuka yang diberikan oleh organisasi federasi guru khususnya organisasi federasi guru terbesarnya yaitu PGRI kepada penguasa daerah hampir tidak pernah ada. Beberapa demonstrasi yang dilakukan guru relatif hanya diikuti oleh para guru swasta yang bersifat sporadis dan kurang terorganisir. Tema yang diusung adalah masalah tuntutan status kepegawaian dan keterlambatan dana insentif. Oleh karenanya, fungsi koordinasi terhadap gerakan kritis relatif tidak dimiliki oleh PGRI. Hal ini seolah berlaku logika berfikir, "bahwa keberanian memberikan kritik berarti keberanian berbeda pandangan dan keberanian berbeda pandangan berarti keberanian melawan sehingga keberanian melawan berarti telah menyediakan diri untuk dikucilkan dan dilengserkan". Logika berfikir demikian itulah yang bisa jadi melatarbelakangi para elit organisasi federasi guru khususnya PGRI yang selama ini tidak berani kritis kepada penguasa daerah.

Realitasnya, perilaku organisasi federasi guru terutama PGRI justru selalu mendukung kebijakan-kebijakan pendidikan yang dibuat oleh pemerintah daerah. PGRI seakan tidak punya nyali untuk bersikap kritis terhadap kebijakan pemerintah daerah yang dianggap banyak pihak sebagai kegagalan kebijakan seperti jatinisasi, babonisasi, dan susunisasi. Dengan demikian kooptasi terhadap organisasi federasi guru berdampak pada melemahnya keberanian mayoritas guru di hadapan penguasa daerah.

Implikasi negatif lainnya akibat dari praktek politisasi guru oleh penguasa daerah adalah terjadinya penurunan jumlah guru sebagai akibat dari hijrahnya banyak guru beralih menjadi pejabat di lingkungan birokrasi pemerintahan. Kooptasi melalui organisasi PGRI di atas juga diiringi dengan berkurangnya jumlah guru yang mengajar di kelas. Dalam arti banyaknya elit PGRI yang semula adalah seorang guru kemudian diangkat oleh penguasa daerah menjadi pejabat teras di lingkungan birokrasi pemerintah telah menyebabkan berkurangnya jumlah guru yang mengajar di dalam kelas. Bahkan lebih jauh lagi implikasi negatif lain berupa munculnya efek domino psikologis yang melanda sebagian guru lainnya yang bercita-cita ingin beralih menjadi pejabat teras di lingkungan birokrasi pemerintahan. Hal ini tentu semakin menggerus kemapanan mayoritas guru yang berstatus sebagai guru kelas.

Mencermati paparan hasil studi tentang data yang berasal dari subbag kepegawaian Dinas Pendidikan Dasar mengindikasikan adanya penurunan jumlah guru secara terus menerus selama tujuh tahun terakhir. Meskipun penurunan jumlah guru tersebut disebabkan banyaknya guru yang telah memasuki usia pensiun, namun tidak dipungkiri juga adalah banyaknya guru yang beralih tugas menjadi pejabat di lingkungan birokrasi pemerintahan kabupaten Bantul. Berkurangnya jumlah guru yang mengajar di kelas pada gilirannya juga berdampak pada menurunnya rasio guru siswa di setiap kecamatan di kabupaten Bantul, baik untuk rasio siswa dengan keseluruhan guru maupun rasio siswa dengan guru negeri serta rasio siswa dengan guru swasta.

Pada sisi yang lain, politisasi guru oleh penguasa daerah dapat berimplikasi positif. Kebijakan peningkatan kualitas diri guru yang tertuang di dalam program pemberian dana bantuan studi lanjut dan program pemberian insentif peningkatan kesejahteraan guru, berdampak pada meningkatnya jumlah guru yang kuliah studi lanjut sehingga sebagian besar guru berhasil menamatkan jenjang strata-1 bahkan diantara guru ada yang menamatkan strata-2 dan strata-3. Selain dapat meningkatkan jumlah guru yang berhasil meraih gelar pendidikan sarjana dan pascasarjana, implikasi positif lain adalah meningkatnya jumlah pendapatan riil yang diterima guru baik yang berstatus sebagai guru negeri maupun swasta. 
Politisasi guru oleh penguasa daerah melalui politik pengambilan hati guru yang dilakukan penguasa daerah dengan memberikan dana bantuan untuk studi lanjut guru dan pemberian insentif penghasilan tambahan bagi guru, dapat dikatakan berhasil menyenangkan hati mayoritas guru. Upaya tersebut dilakukan oleh penguasa daerah dengan membuat payung hukum terlebih dahulu sebagai bentuk legalisasi tindakannya berupa Perbup Nomor 24 Tahun 2007 tentang Pedoman Pemberian Bantuan Pendidikan Tugas Belajar dan Pemberian Bantuan Pendidikan Ijin Belajar Bagi Pegawai Negeri Sipil Daerah. Bantuan studi lanjut bagi guru-guru guru non-PNS juga dilegalkan dalam Perbup Nomor 38 Tahun 2008 tentang Pedoman pemberian Bantuan Pendidikan Lanjutan bagi Guru Bukan Pegawai Negeri Sipil. Adapun untuk pemberian insentif penghasilan tambahan guru PNS dituangkan dalam Perbup Nomor 28 Tahun 2007 tentang Pemberian Penghasilan Tambahan PNS. Pemberian insentif penghasilan tambahan untuk guru non-PNS atau guru honor/ kontrak dituangkan dalam Perbup Nomor 21 Tahun 2007 tentang Pemberian Tunjangan Kesejahteraan bagi Dokter PTT, Bidan PTT dan Guru Bantu di Lingkungan Pemerintah Kabupaten Bantul.

Upaya pemberian dana bantuan untuk studi lanjut guru dan pemberian insentif penghasilan tambahan bagi guru secara nyata tampak adanya perhatian pemerintah daerah kepada nasib guru, sehingga guru secara relatif semakin meningkat kemakmurannya. Dengan meningkatnya kemakmuran guru menyebabkan guru tidak lagi harus mencari penghasilan tambahan ke sana dan ke mari, seperti mengojek dan memberi les tambahan di luar jam mengajar.

Namun demikian, di balik pemberian dana bantuan studi lanjut dan pemberian insentif penghasilan tambahan bagi guru di atas ada motif terselubung dari Bupati. Motif terselubung itu adalah usaha Bupati untuk menguasai guru. Hal inilah yang dipandang sebagai 'jurus mengambil hati guru' oleh Bupati sebagai pusat kekuasaan di daerah. Program pemberian dana bantuan studi lanjut dan program pemberian insentif peningkatan kesejahteraan guru juga dapat dikatakan 'program pemanjaan guru' sebagai 'jurus mengambil hati guru'. Hal ini dikarenakan guru merupakan suatu profesi dengan jumlah personil paling banyak secara kuantitatif. Dengan demikian Bupati semakin memperoleh legitimasi kuat dari golongan profesi terbesar, dan Bupati tetap terpilih kembali pada dua kali pemilukada terakhir.

Implikasi positif lain dari praktek politisasi guru oleh penguasa daerah adalah adalah adanya kemajuan dalam pengembangan profesionalisme guru. Ukuran profesionalisme guru mencakup empat aspek kompetensi guru sebagaimana yang tertuang di dalam Undang-Undang RI Nomor 14 tahun 2005 tentang Guru dan Dosen, yang telah dijabarkan ke dalam PP Nomor 19 Tahun 2005 tentang Standar Nasional Pendidikan dan PP Nomor 74 Tahun 2008 tentang Guru. Ukuran formal peningkatan profesionalisme guru dapat dilihat dari hasil sertifikasi guru yang telah dilakukan oleh konsorsium sertifikasi guru Indonesia.

Hal tersebut dapat dicermati dari data laporan Badan Kepegawaian Daerah (BKD) Pemkab Bantul tentang jumlah guru yang telah mengikuti uji sertifikasi dan telah dinyatakan lulus. Hasil uji sertifikasi guru sebagaimana dilaporkan BKD menunjukkan adanya angka kenaikan jumlah guru-guru di kabupaten Bantul yang telah lulus dalam uji sertifikasi, namun demikian tak lama kemudian diikuti dengan penurunan jumlah guru yang tersertifikasi. Selama tujuh tahun terakhir sejak awal dilakukannya uji sertifikasi guru oleh konsorsium sertifikasi guru Indonesia, jumlah guru yang tersertifikasi di kabupaten Bantul menunjukkan data naik di awal sampai tahun kelima dan kemudian turun sedikit di tahun keenam dan semakin turun tajam di tahun ketujuh.

Pada tabel tersebut menunjukkan bahwa pada tahun 2006 merupakan awal diadakannya sertifikasi guru, dimana dari total guru yang berjumlah 4.921 orang, namun yang sudah tersertifikasi baru 40 guru, yang berarti baru 00,81\%. Namun pada tahun kedua sampai tahun kelima secara berturutturut yaitu tahun 2007, 2008, 2009, dan 2010 terjadi kenaikan persentase guru yang telah tersertifikasi yaitu dari $05,88 \%$ kemudian $06,74 \%, 06,76 \%$, saampai $12,59 \%$. Akan tetapi pada tahun 2011 dan 2012 terjadi penurunan lagi menjadi $10,55 \%$ dan $03,64 \%$.

Naik turunnya jumlah guru yang tersertifikasi tersebut lebih dipengaruhi oleh quota yang diberikan oleh pemerintah pusat 
serta banyaknya jumlah guru yang telah tersertifikasi namun pada akhirnya memasuki usia purna tugas alias pensiun, sehingga jumlah guru yang tersertifikasi khususnya pada tahun 2012 menjadi amat sedikit.

Selain jumlah dan persentase guru SD yang tersertifikasi sehingga dianggap sebagai guru professional sebagaimana telah dipaparkan di atas, implikasi lain adalah pada peningkatan kepangkatan guru dari tahun ke tahun.

Data-data yang diperoleh menunjukkan adanya penurunan dari tahun ke tahun mengenai jumlah guru dengan kepangkatan/ golongan ruang II, III/a, III/b, III/c, dan III/d, namun jumlah guru dengan kepangkatan/ golongan ruang IV/a, IV/b, dan IV/c mengalami peningkatan. Hal ini dapat dimaknai sebagai kemajuan karena banyak guru yang relatif lancar dalam kenaikan pangkatnya secara periodik. Bahkan secara keseluruhan sekitar $80 \%$ guru di kabupaten Bantul memiliki kepangkatan/ golongan ruang IV/a, dan sudah ada 3 orang guru SD yang telah mencapai kepangkatan/golongan ruang IV/c.

Namun demikian masih ada keprihatinan yakni masih ada guru dengan golongan II relatif banyak meskipun dari tahun ke tahun mengalami penurunan. Padahal syarat kualifikasi akademik sebagaimana dikehendaki Undang-Undang RI nomor 14 Tahun 2005 adalah minimal sarjana strata-1, yang berarti setara dengan kepangkatan/ golongan ruang minimal III/a. Oleh karena itu menjadi kewajiban guru yang bersangkutan serta bagi organisasi profesi dan pemerintah daerah untuk mendorong guru tersebut agar dapat meningkatkan kualifikasi akademiknya minimal setara strata-1 serta kepangkatan/golongan ruang minimal III/a.

Selain mengenai sertifikasi dan kepangkatan guru, implikasi positif lain juga dapat menyangkut peningkatan secara relatif jumlah guru SD di Kabupaten Bantul yang memiliki berprestasi, baik tingkat kabupaten, propinsi, maupun nasional selama lima tahun terakhir. Data-data yang ditemukan menunjukkan adanya peningkatan prestasi guru SD kabupaten Bantul dalam kompetisi guru berprestasi untuk tingkat kabupaten, propinsi, nasional. Namun relatif kecil, bahkan cenderung menurun lagi untuk tahun terakhir. Jumlah guru berprestasi tingkat kabupaten relatif tetap, namun jumlah guru berprestasi untuk tingkat propinsi dan nasional relatif menga- lami peningkatan namun tidak begitu signifikan bahkan cenderung turun untuk tahun terakhir. Terutama untuk lima tahun terakhir sejak tahun 2008 sampai tahun 2012, guru berprestasi untuk tingkat nasional baru dicapai pada tahun 2011 dan tahun 2012 menurun lagi.

Lebih jauh lagi, menyangkut studi lanjut guru dapat diketahui dari dokumen yang bersumber dari Laporan Tahunan yang dibuat oleh Sub-bidang Analisis dan Perencanaan Diklat kantor Badan Kepegawaian Daerah (BKD) Pemkab Bantul. Dokumen yang tersaji pada tabel tampilan-20 diketahui bahwa sejak tahun 2008 sampai tahun 2012 ditemukan data jumlah PNS Pemkab Bantul yang lulus studi lanjut untuk jenjang S-1 dan S-3 mengalami peningkatan, namun untuk jenjang S-2 mengalami penurunan.

Dari data tersebut menunjukkan jumlah PNS termasuk di dalamnya adalah guru PNS yang berhasil lulus dalam studi lanjut baik jenjang strata-1, strata-2, maupun strata-3. Jumlah yang terbanyak adalah yang lulus strata-1 untuk tahun 2008 sampai 2012 mengalami peningkatan secara signifikan dari tahun ke tahun dalam lima tahun tersebut. Begitu juga yang lulus strata-3 juga mengalami peningkatan dari tidak pada tahun 2008 sampai 2010 kemudian pada tahun 2011 dan 2012 menjadi ada meskipun hanya 1 orang PNS yang berhasil lulus pada tahun tersebut. Rata-rata PNS yang menempuh studi lanjut pada jenjang strata-1 dan strata-2 dengan menggunakan fasilitas bantuan ijin belajar, namun PNS yang menempuh studi lanjut jenjang strata-3 lebih memilih menggunakan fasilitas bantuan tugas belajar.

Menariknya adalah jumlah PNS yang berhasil lulus pendidikan strata-2 justru semakin menurun dari tahun ke tahun, terutama jumlah yang lulus dengan status tugas belajar semakin menurun. Pertanyaannya adalah mengapa demikian? Apakah komitmen pemerintah daerah sudah mengalami penuruan? Padahal pengakuan dari IS, seorang mantan Bupati yang juga sebagai suami dari Bupati yang sekarang berkuasa, menyebutkan program studi lanjut di kabupaten Bantul telah menjadikan Bantul menjadi salah satu kabupaten yang memiliki guru berpendidikan S-2 terbanyak. Tahun 2004 katanya telah berhasil mengirimkan 124 guru untuk mengambil studi lanjut di program 
pascasarjana yang didukung dana APBD. Untuk beberapa tahun terakhir pemerintah daerah akan mengeluarkan dana lebih dari 2 milyar per tahun.

Dari data PNS yang telah berhasil lulus melakukan studi lanjut tersebut mencakup keseluruhan PNS yang ada di kabupaten Bantul, namun mayoritas diantara mereka adalah guru yang bertugas mengajar pada jenjang pendidikan dasar dan menengah di kabupaten Bantul. Apabila diteliti lebih mendalam dengan cara memilihnya yang benarbenar berstatus sebagai PNS guru SD, maka dapat dicermati dari tabel tampilan-21 di atas. Pada tampilan-21 tersebut diketahui bahwa guru SD PNS yang studi lanjut ke Strata-1 jumlahnya mayoritas, meskipun bersifat fluktuatif, yakni pada awalnya mengalami kenaikan kemudian sejak tahun 2010 mengalami penurunan. Begitu juga guru SD yang berstatus PNS yang berhasil lulus studi lanjut strata-2 jumlahnya fluktuatif, hanya saja fluktuasinya berbeda yakni mengalami penurunan kemudian kenaikan.

Secara keseluruhan jumlah guru SD yang mengikuti dan lulus dalam studi lanjut tidak sedramatis sebagaimana dinyatakan oleh penguasa daerah terutama ketika kekuasaan di daerah secara formal dipegang oleh istri dari penguasa lama. Pada rentang waktu sekitar dua pertiga dari kekuasaan rezim lama ketika nama bupatinya berinisal IS, program kebijakan 'pascasarjanisasi' dapat dikatakan berlangsung amat dramatis seiring dengan kebijakan 'insentifisasi', bahkan seiring juga dengan program-program lain yang dikenal masyarakat dengan nama program babonisasi dan jatinisasi. Namun setelah memasuki tahun 2011 atau era rentang waktu sepertiga dari kekuasaan rezim IS tersebut, kebijakan andalan yakni 'pascasarjanisasi' dan 'insentifisasi' mengalami penurunan.

\section{SIMPULAN}

Kesimpulan yang dapat ditarik dari penelitian ini adalah: pertama, bahwa peningkatan otonomi guru menuju sosok profesional adalah upaya yang banyak dipengaruhi oleh dinamika politik. Para aktor politik menginginkan peningkatan otonomi guru diarahkan untuk peningkatan profesionalitas yang mendukung pencapaian kemajuan masyarakat di daerah, sedangkan pihak guru menginginkan peningkatan otonominya merupakan wujud pemenuhan kewajiban undang-undang berupa peningkatan kualifikasi dan kompetensi guru demi kemajuan pendidikan. Semua pihak memiliki titik temu pada peningkatan profesionalitas guru sebagai perwujudan otonomi guru. Sebagian guru kurang otonom dan terlibat dalam politik praktis dengan alasan pribadi sebagai warga negara, mereka melakukan secara sembunyi-sembunyi yang mereka sebut 'main lewat belakang', guru swasta melibatkan diri dalam politik praktis secara terang-terangan melalui kontrak politik, demonstrasi, dan audiensi.

Kedua, terdapat politik dominasi oleh penguasa daerah terhadap otonomi guru yang lebih dikenal dengan 'politisasi guru' baik secara tersurat maupun tersirat untuk meraih 'kepentingan politik'. Praktek tersebut merupakan wujud dari political relation yang menjelma menjadi transaksi politik yang berujung pada pembagian kekuasaan.

Ketiga, 'politisasi guru' dirancang sedemikian rupa oleh penguasa daerah dalam bentuk 'praktek terselubung' dengan tujuan untuk 'meraih dukungan' dari masyarakat luas melalui guru. Hasil pekerjaan guru terlihat dari hasil Pemilukada 2010 dimana calon yang didukung guru menang telak (68\%), sampai awal tahun 2013 tidak ada gejolak politik. Atas jerih payah guru tersebut, penguasa daerah memberikan 'imbalan jasa politik' dalam bentuk 'jabatan politik'. Ada dua bentuk politisasi guru oleh penguasa daerah, yaitu melalui politik kooptasi atas organisasi federasi guru, dan melalui politik pengambilan hati guru.

Keempat, politisasi guru yang dilakukan oleh penguasa daerah berimpilkasi baik negatif maupun positif terhadap guru. Implikasi negatifnya adalah melemahnya sikap kritis guru baik secara individual, kolektif, maupun institusional terhadap segenap kebijakan pendidikan pemerintah daerah. Implikasi positifnya adalah meningkatnya jumlah guru yang studi lanjut, bertambahnya jumlah guru yang berprestasi dan lulus dalam uji sertifikasi, sert meningkatnya tingkat kesejahteraan guru.

\section{DAFTAR PUSTAKA}

Almond, G.A. (1974). Interest groups and interest articulation. dalam Gabriel A. 
Almond (ed). 1974. "Comparative politics todays: a world view”. Boston: Crown and Company.

Collins, R. (1979). The Credentials Society: An Historical Sociology of Education and Stratification. New York: Academic Press.

Creswell, J. W. (2007). Qualitative inquiry \& research design: choosing among five approaches (second edition). London: Sage publications.

Giroux, H A. \& Mc Laren, PL. (1989). Critical pedagogy, the state, and cultural struggle. New York: State University of New York.

Hadisusanto, D., Sidharto, S., \& Siswoyo, D. (1995). Pengantar ilmu pendidikan. Yogyakarta: FIP IKIP Yogyakarta.

Joni, T.R. (1991). Pokok-pokok pikiran mengenai pendidikan guru, dalam Conny R. Semiawan dan Soedijarto (ed) Mencari Strategi Pembangunan Pendidikan Nasional Menjelang Abad XXI. Jakarta: Gramedia.
Koesoema, D. (2009). Guru sebagai pelaku transformasi sosial. Makalah pada "Simposium Guru dalam perubahan sosial politik bangsa" Diselenggarakan di Aula SMU 6 Bulungan Jakarta, 15 Mei 2009, oleh kerjasama MGMP Sejarah propinsi DKI, Asosiasi Guru Sejarah Indonesia (AGSI), dan Institut Sejarah Sosial Indonesia (ISSI).

Kompas Jakarta, tanggal 12 Mei 2010.

Laksana, S.D. (2011). Kasihanilah kepala daerah. Artikel Kedaulatan Rakyat. Yogakarta, 24 Nopember 2011

Media Indonesia Jakarta, tanggal 19 April 2000.

Spring, J. (1993). Conflict of Interests: the politics of American education. New York: Longman.

Sugiono, M. (1999). Kritik Antonio Gramsci terhadap pembangunan dunia ketiga. Yogyakarta: Pustaka Pelajar.

Tilaar, HAR. (2003). Kekuasaan dan pendidikan. Magelang: Indonesiatera. 